\title{
A Study on Electrical Characteristics and Optimization of Trench Power MOSFET for Industrial Motor Drive
}

\author{
Ey Goo Kang **
}

\begin{abstract}
Power MOSFET is developed in power savings, high efficiency, small size, high reliability, fast switching, and low noise. Power MOSFET can be used in high-speed switching transistors devices. Recently attention given to the motor and the application of various technologies. Power MOSFET is a voltage-driven approach switching device and designed to handle on large power, power supplies, converters, motor controllers. In this paper, the $400 \mathrm{~V}$ Planar type, and the trench type for realization of low on-resistance are designed. Trench Gate Power MOSFET Vth : 3.25 V BV : 484 V Ron : 0.0395 Ohm has been optimized.
\end{abstract}

Keywords: Power MOSFET, Planar process, Trench process, Breakdown voltage, On resistance, P-base dose

\section{Introduction}

The power MOSFET, a device operated in a voltage drive method and a switching device designed to handle big power, is widely used in a power supply device, converter, motor controller, etc. The Power MOSFET has low on-state resistance, so it can raise efficiency by reducing power transmission loss in an operating condition, eventually enabling low-power realization.[1-3] This study designed a $400 \mathrm{~V}$ grade Planar Power MOSFET, designed and simulated a 400V

grade Trench type Power MOSFET based on this, and analyzed its breakdown voltage and on-state resistance characteristics through this. [4-5]

* Dept. of Photovoltaic Engineering, Far East University

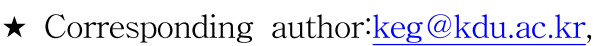
Tel:+82-43-879-3590

Manuscript received Aug. 16, 2013; revised Sep. 15,2013 ; accepted Sep 16. 2013

\section{Experiment Method}

2.1 Design of a 400V Grade Planar Power MOSFET

Before designing a Trench Power MOSFET of 400V grade breakdown voltage, this study basically designed and optimized a planar
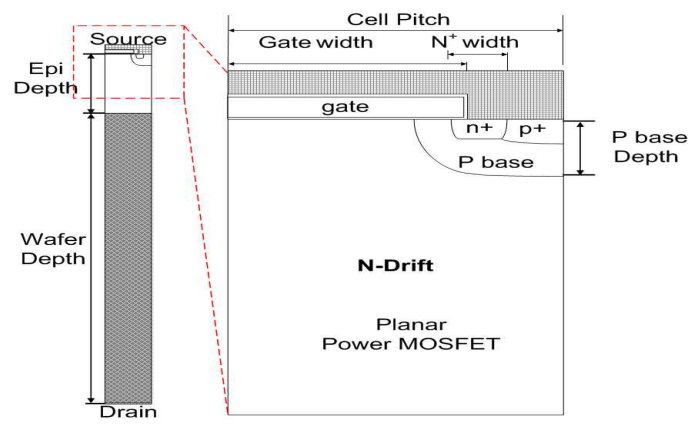

Fig. 1. The structure of $400 \mathrm{~V}$ Planar Power MOSFET

power MOSFET of the same unit cell size as a Trench Power MOSFET. This study designed a basic Planar Power MOSFET structure of over 400V 
grade through a simulation, whose final design structure and parameter value are shown in Fig.1 and Table 1 below. The simulation tool was used TCAD.

Table 1. The design and process parameters of $400 \mathrm{~V}$ Planar Power MOSFET Parameter

\begin{tabular}{|c|c|}
\hline Parameter & $400 \mathrm{~V} / 20 \mathrm{~A}$ \\
\hline Cell Pith & $8.25 \mu \mathrm{m}$ \\
\hline Gate width & $4.25 \mu \mathrm{m}$ \\
\hline $\mathrm{N}+$ width & $1 \mu \mathrm{m}$ \\
\hline Epi Depth & $40 \mu \mathrm{m}$ \\
\hline $\mathrm{P}$ base Depth & $3.25 \mu \mathrm{m}$ \\
\hline Wafer Depth & $320 \mu \mathrm{m}$ \\
\hline Epi resistivity & $9.75 \Omega \mathrm{cm}$ \\
\hline Wafer resistivity & $0.018 \Omega \mathrm{cm}$ \\
\hline $\mathrm{P}+$ Source dose & $\begin{array}{c}3 \mathrm{e} 15 \mathrm{~cm}^{-2} \\
\text { Energy } 120 \mathrm{KeV}\end{array}$ \\
\hline $\mathrm{P}$ Base dose & $\begin{array}{c}4 \mathrm{e} 13 \mathrm{~cm}^{-2} \\
\text { Energy } 80 \mathrm{KeV}\end{array}$ \\
\hline N JFET dose & $\begin{array}{c}1 \mathrm{E} 10 \mathrm{~cm}^{-2} \\
\text { Energy } 100 \mathrm{KeV}\end{array}$ \\
\hline $\mathrm{N}+$ Source dose & $\begin{array}{c}5 \mathrm{E} 15 \mathrm{~cm}^{-2} \\
\text { Energy } 100 \mathrm{KeV}\end{array}$ \\
\hline
\end{tabular}

The operating characteristics of a $400 \mathrm{~V}$ grade Planar Power MOSFET are shown in Fig.2 and Table 2 below.

\subsection{Design of a $400 \mathrm{~V}$ Trench Power MOSFET}

A trench gate was applied to an optimized 400V Planar Power MOSFET structure. A simulation was carried out, with Cell Pitch, Epi Depth, Wafer depth, Epi resistivity and Gate Width fixed. Fig.3 below shows a basic structure of Trench Power MOSFET.
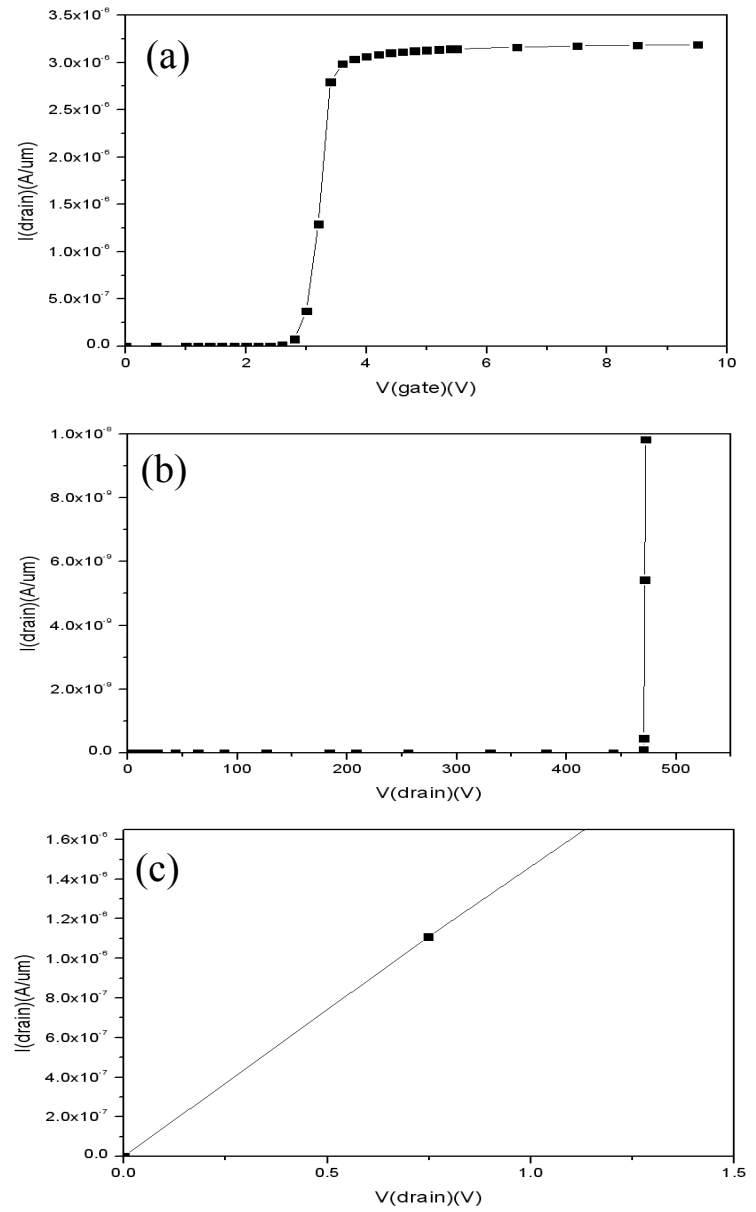

Fig. 2. The electrical characteristics of optimal planar Power MOSFET. (a) Vth, (b) BV, (c) Ron.

Table 2. The electrical characteristics of optimal planar Power MOSFET.

\begin{tabular}{ccc}
\hline Vth & BV $(\mathrm{V})$ & Ron@20 A \\
\hline $3.1 \mathrm{~V}$ & $470 \mathrm{~V}$ & 0.056 \\
\hline
\end{tabular}

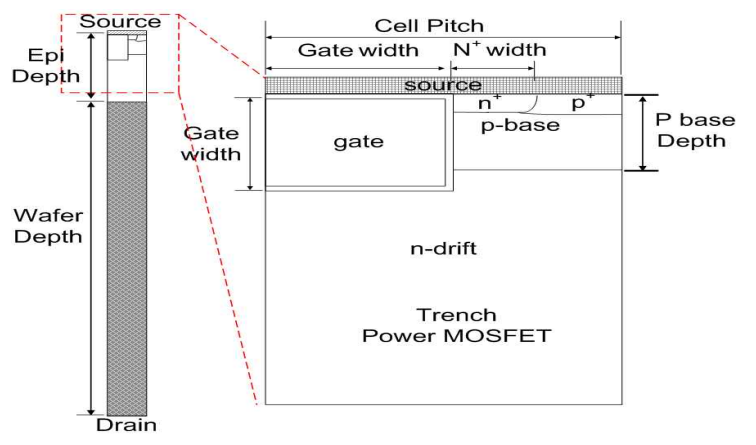

Fig.3. The structure of $400 \mathrm{~V}$ Trench Power MOSFET 
2.3 Breakdown voltage and on-state resistance simulation depending on trench gate depth

This paper gave a condition of gate depth as 3.1 3.9 um. The Trench Power MOSFET reduces the JFET area and drift area by etching the gate differently from the Planar Power MOSFET. It could be seen that this can reduce on-state resistance compared to the Planar Power MOSFET structure. However, etching the gate too deep can reduce breakdown voltage due to the concentrated electric field on the increased part of gate etching depth without increasing the electric field uniformly, so the simulation was carried out by paying attention to this. This simulation was carried out with a criterion because 3.5 um was judged to be suitable.

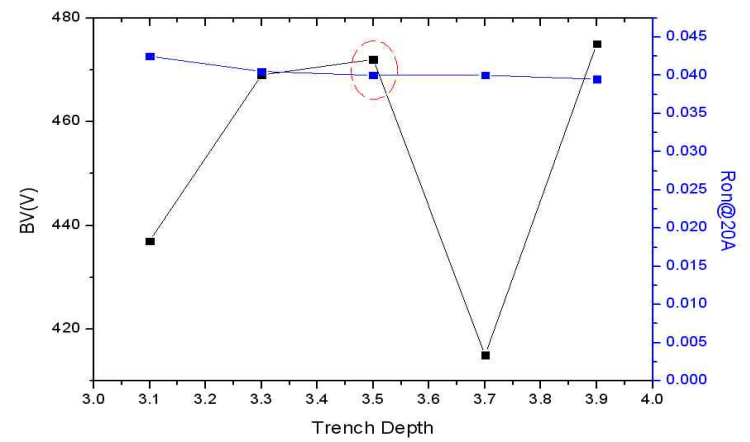

Fig. 4. The breakdown voltage and on resistance of trench power MOSFET according to Trench depth

Table 3. The breakdown voltage and on resistance of trench power MOSFET according to Trench depth

\begin{tabular}{ccc}
\hline $\begin{array}{c}\text { Trench } \\
\text { Depth }(\mu \mathrm{m})\end{array}$ & BV $(\mathrm{V})$ & Ron@20 A \\
\hline 3.1 & 437 & 0.0425 \\
\hline 3.3 & 469 & 0.0405 \\
\hline 3.5 & 472 & 0.04 \\
\hline 3.7 & 415 & 0.04 \\
\hline 3.9 & 475 & 0.0395 \\
\hline
\end{tabular}

2.4 Threshold voltage and on-state resistance simulation depending on $\mathrm{P}$-base dose

A condition of $\mathrm{P}-$ base dose $1.0 \mathrm{E} 13 \sim 3.0 \mathrm{E} 13 \mathrm{~cm}^{-2}$ was given, with the previous results fixed. If the
$\mathrm{P}$-base dose increases, the gate voltage should be increased to form a channel, so the threshold voltage increases, but if the threshold voltage is high, the switching speed decreases, so it should be designed low. If the threshold voltage decreases, the switching time is improved, but undesired turn-on may happen due to the gate voltage raised during switching. In addition, the Trench Power MOSFET creases a channel beside the trench gate differently from the Planar Power MOSFET, so concentration was set differently to obtain the same threshold voltage. This paper assumed threshold voltage as $3.0 \sim 4.0 \mathrm{~V}$, so $3.2 \mathrm{~V}$ was obtained per $1.5 \mathrm{E} 13 \mathrm{~cm}^{-2}$ suitable for this condition and the on-state resistance was also low, therefore $1.5 \mathrm{E} 13 \mathrm{~cm}^{-2}$ was adopted.

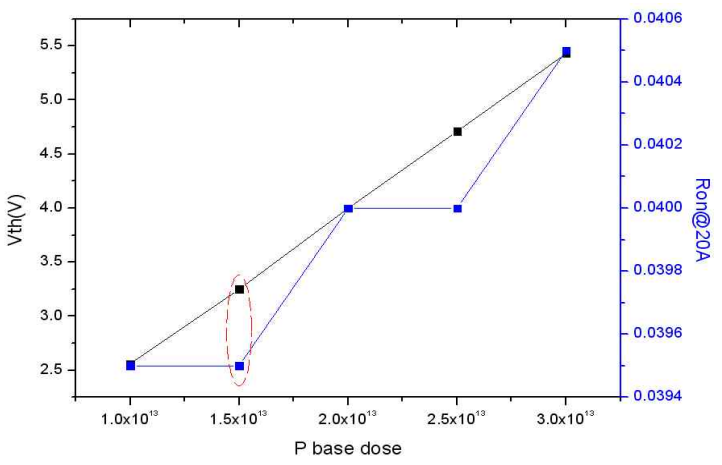

Fig. 5. The threshold voltage and on resistance characteristics according to P-base dose

Table 4. The threshold voltage and on resistance characteristics according to P-base dose

\begin{tabular}{ccc}
\hline $\begin{array}{c}\text { P Base } \\
\text { dose }\left(\mathrm{cm}^{-2}\right)\end{array}$ & $\mathrm{V}_{\text {th }}(\mathrm{V})$ & Ron@20 A \\
\hline $1.0 \mathrm{e} 13$ & 2.56 & 0.0395 \\
\hline $1.5 \mathrm{e} 13$ & 3.25 & 0.0395 \\
\hline $2.0 \mathrm{e} 13$ & 4.0 & 0.04 \\
\hline $2.5 \mathrm{e} 13$ & 4.71 & 0.04 \\
\hline $3.0 \mathrm{e} 13$ & 5.43 & 0.0405 \\
\hline
\end{tabular}

The comparison contents of Planar and Trench are shown in Fig.6 and Table 5 respectively. It could be seen that on-state resistance was reduced due to the Trench gate. 

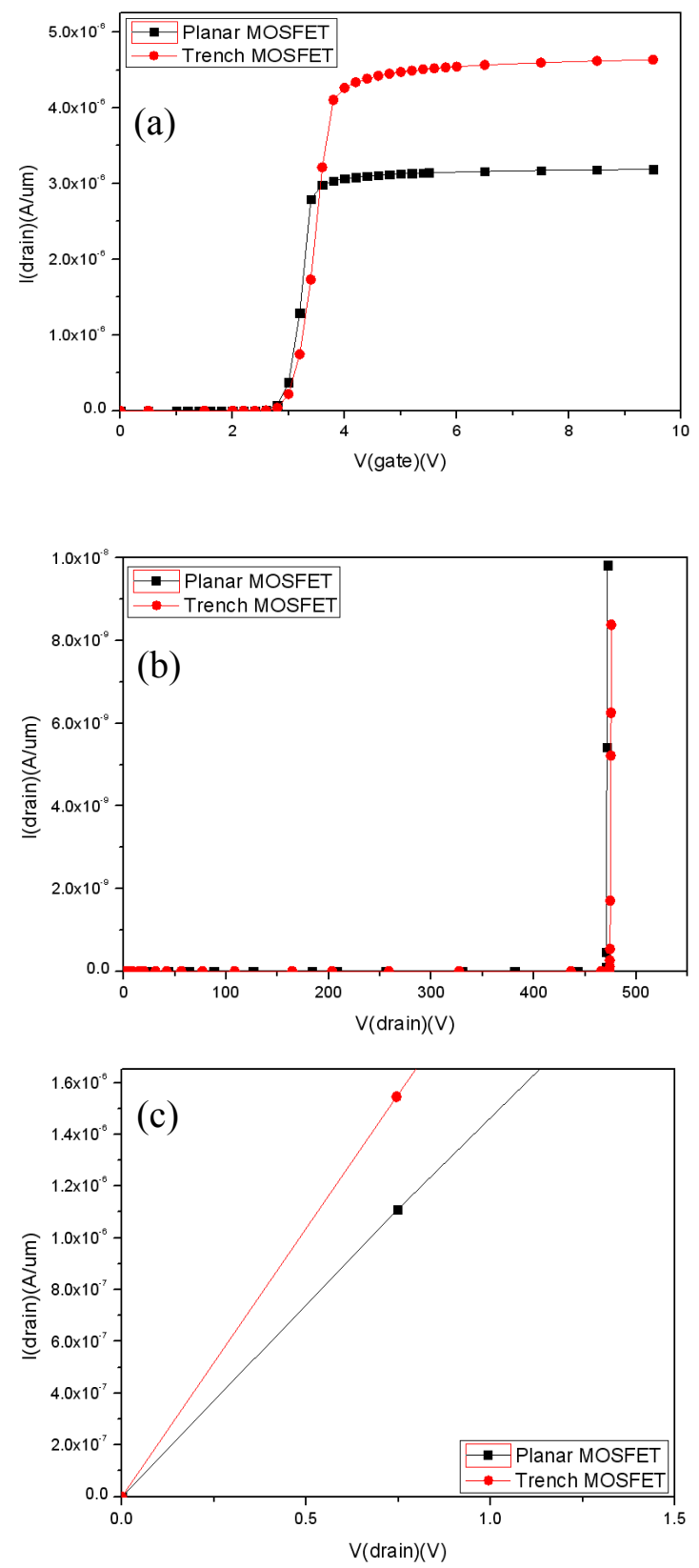

Fig. 6. The electrical characteristics of optimal Planar and trench power MOSFETs (a) Vth, (b) BV, (c) Ron.

Table 5. The electrical characteristics of optimal Planar and trench power MOSFETs (a) Vth, (b) BV, (c) Ron.

\begin{tabular}{cccc}
\hline Type & $\begin{array}{c}\mathrm{V}_{\text {th }} \\
(\mathrm{V})\end{array}$ & BV(V) & $\begin{array}{c}\text { Ron } \\
@ 20 \mathrm{~A}\end{array}$ \\
\hline Planar & 3.1 & 470 & 0.056 \\
\hline Trench & 3.25 & 473 & 0.0395 \\
\hline
\end{tabular}

2.5 Breakdown voltage on-state resistance simulation depending on cell pitch and gate area

The gate area was reduced to $8.25 \sim 6.25$ um depending on cell pitch and designed as $4.25 \sim 2.25$ um through reduction by $1 \mathrm{um}$ in proportion to the cell pitch.

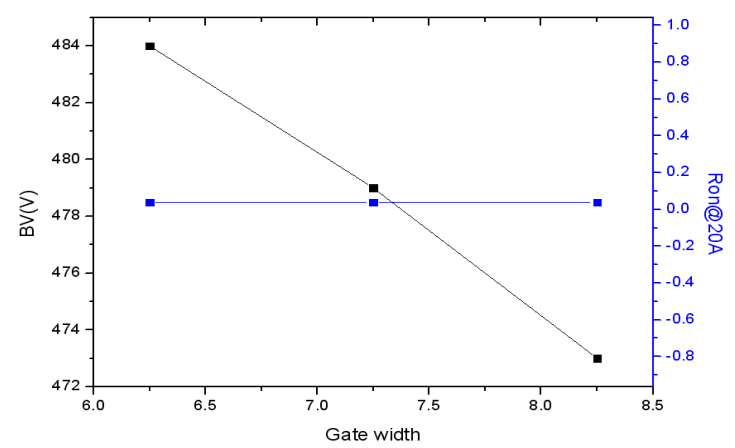

Fig. 7. The breakdown voltage and on resistance characteristics of trench power MOSFET according to cell pitch, gate width

Table 6. The breakdown voltage and on resistance characteristics of trench power MOSFET according to cell pitch, gate width

\begin{tabular}{cccc}
\hline $\begin{array}{c}\text { Cell } \\
\operatorname{pitch}(\mu \mathrm{m})\end{array}$ & $\begin{array}{c}\text { Gate } \\
\text { width }(\mu \mathrm{m})\end{array}$ & BV(V) & $\begin{array}{c}\text { Ron } \\
@ 20 \mathrm{~A}\end{array}$ \\
\hline 8.25 & 4.25 & 473 & 0.0395 \\
\hline 7.25 & 3.25 & 479 & 0.0395 \\
\hline 6.25 & 2.25 & 484 & 0.0395 \\
\hline
\end{tabular}

As a result of simulation, it could be seen that it is possible to raise the efficiency per net die compared to the Planar Power MOSFET by reducing the device cell length of a Trench Power MOSFET.

\section{Result and Consideration}

The final 400V grade Trench Power MOSFET was simulated, whose optimized parameters and characteristics are shown in Fig.8, 9 and Table 7 and 8 below. 

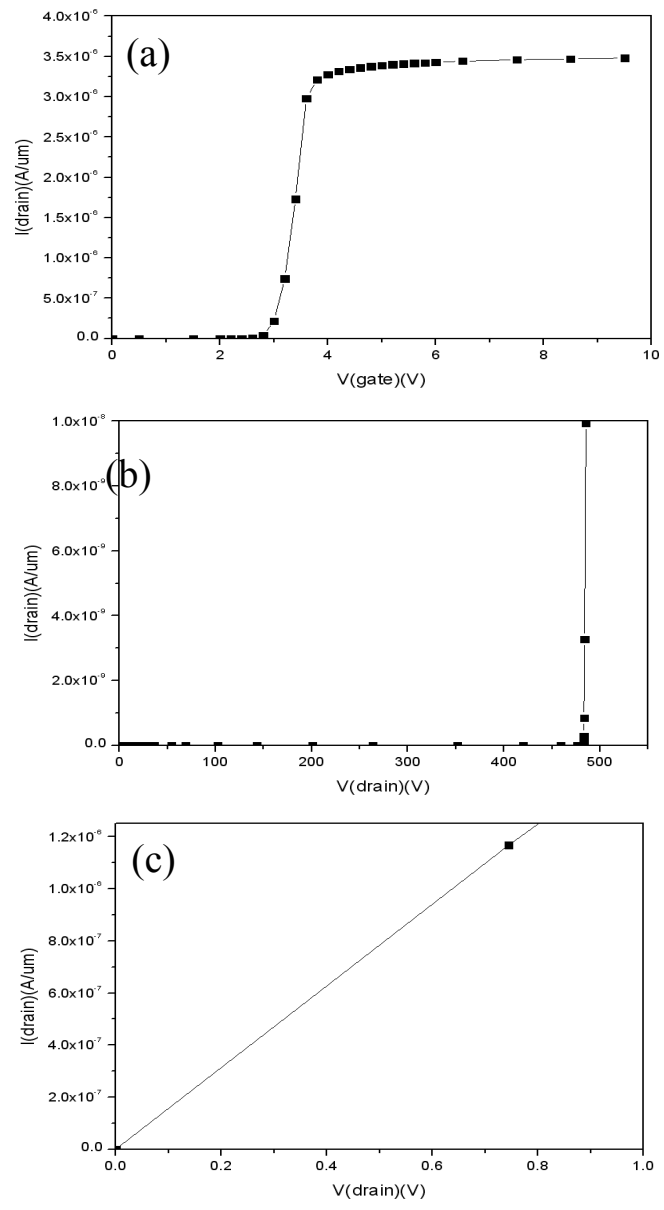

Fig. 8. The electrical characteristics of optimal trench power MOSFET (a) Vth, (b) BV, (c) Ron.

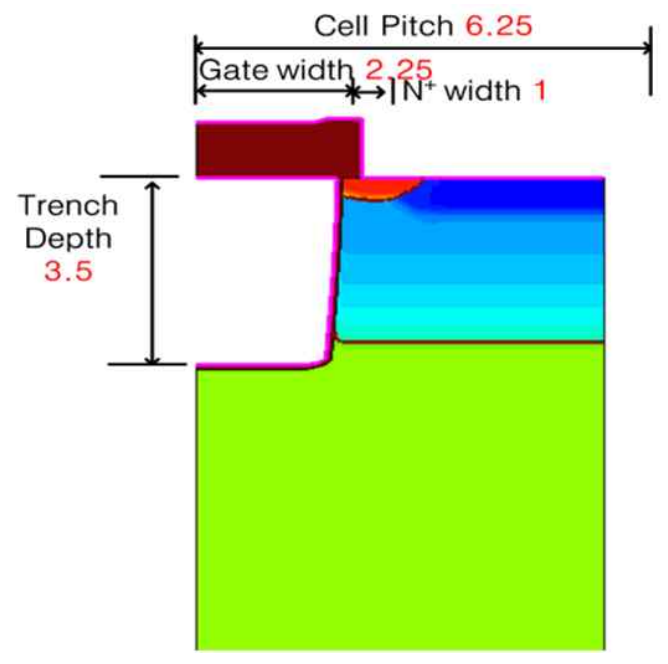

Fig. 9. Trench Power MOSFET optimiation sectional view.
Table 7. The electrical characteristics of optimal trench power

\begin{tabular}{ccc} 
MOSFET & & \\
\hline $\mathrm{V}_{\mathrm{th}}(\mathrm{V})$ & $\mathrm{BV}(\mathrm{V})$ & Ron@20 A \\
\hline 3.25 & 484 & 0.0395 \\
\hline
\end{tabular}

Table 8. Optimal design and process parameter $400 \mathrm{~V}$ sized trench power MOSFET.

\begin{tabular}{|c|c|}
\hline Parameter & $400 \mathrm{~V} / 20 \mathrm{~A}$ \\
\hline Cell Pith & $6.25 \mu \mathrm{m}$ \\
\hline Gate width & $2.25 \mu \mathrm{m}$ \\
\hline Trench Depth & $3.5 \mu \mathrm{m}$ \\
\hline $\mathrm{N}+$ width & $1 \mu \mathrm{m}$ \\
\hline Epi Depth & $40 \mu \mathrm{m}$ \\
\hline P base Depth & $3 \mu \mathrm{m}$ \\
\hline Wafer Depth & $320 \mu \mathrm{m}$ \\
\hline Epi resistivity & $9.75 \Omega \mathrm{cm}$ \\
\hline Wafer resistivity & $0.018 \Omega \mathrm{cm}$ \\
\hline $\mathrm{P}+$ Source dose & $\begin{array}{c}3 \mathrm{e} 15 \mathrm{~cm}^{-2} \\
\text { Energy } 120 \mathrm{KeV}\end{array}$ \\
\hline P Base dose & $\begin{array}{c}1.5 \mathrm{e} 13 \mathrm{~cm}^{-2} \\
\text { Energy } 80 \mathrm{KeV}\end{array}$ \\
\hline $\mathrm{N}+$ Source dose & $\begin{array}{c}5 \mathrm{E} 15 \mathrm{~cm}^{-2} \\
\text { Energy } 100 \mathrm{KeV}\end{array}$ \\
\hline
\end{tabular}

\section{Conclusion}

As a result of simulation, the Trench Power MOSFET can reduce on-state resistance of the trench gate part on the JFET area compared to the Planar Power MOSFET. Also, the efficiency could be raised by reducing power supply loss with low on-resistance by reducing the resistance in the drift area. In addition, by reducing the cell size, the Trench Power MOSFET can have higher efficiency than the Planar Power MOSFET and raise the breakdown because the number of net dies increases.

\section{References}

[1] Fujihira, T, Proc. of the ISPSD'98, Kyoto(1998), pp.423-426

[2] H. Ninomiya, Y.Miura and K Kobayashi, Proc. ISPSD(2004), pp.177-180

[3] Pravin N. Kondekar, TENCON Vol.4(2003), 
pp. $1455-1458$.

[4] S. Iwamoto, K. Takahashi, H. Kuribayashi, S. Wakimoto, K. Mochizuki and H. Nakazawa, Power Semiconductor Devices and Ics, Proceedings. ISPSD'05. The 17thInternationalSymposiumon(2005), pp.31-34

[5] Yoshiyuki Hattori, Kyoko Nakashima, Makoto Kuwahara, Tomoyuki Yoshida, Shoichi Yamauchi and Hitoshi Yamaguchi, Proceedings of International symposium on Power Semiconductor Devices \& ICs, Kitakyushu(2004), pp.189-192

[6] E.G. Kang, S.H. Moon and M.Y. Sung, Microelectronics journal, Vol.32, Issue.8(2001), pp.641-647

[7] E.G. Kang and M.Y. Sung, Solid-State Electronics, Vol.46, Issue.2(2002), pp.295-300

\section{BIOGRAPHY}

\section{EyGooKang (Life Member)}

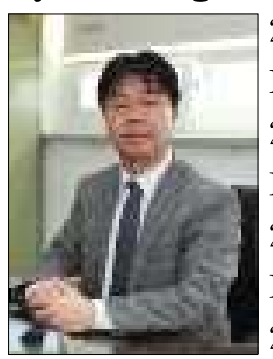
2000 : BS degree in Electrical Engineering, Korea University. 2005 : MS degree in Electrical Engineering, Korea University. 2006 : PhD degree in Electrical Engineering, Korea University. 2003 present : professor in department of photo voltaic engineering, Far East University 